\title{
Impact assessment on air quality due to widening of a highway by using CALINE software
}

\author{
U. S. Kulkarni \& H. A. Keshwani \\ Fine Envirotech Engineers, Mumbai, India
}

\begin{abstract}
A complete assessment of the impacts caused due to widening of a National Highway on the air, water and soil environment in the nearest vicinity and $10 \mathrm{kms}$ study area has been carried out and results presented. The Pune-Solapur National Highway-9 from km 144.00 to $\mathrm{km} 249.00$ chainage has to be widened from existing 2 lane carriageway to 4/6 lane carriageway. The said project has been accorded Environmental Clearance from the Ministry of Environment and Forests (MoEF), Govt. of India, in the month of September 2011. The baseline study of the site comprising ambient air, noise, surface/ ground water, soil, landuse, ecological biodiversity and socio-economic factors of the area in $10 \mathrm{kms}$ from the proposed widening site was carried out. Since the proposed project is a highway project, major air pollutants from the widening shall be vehicular exhaust emission from the increased traffic. This being a line source can be predicted through CALINE software. Study of ambient level of existing carbon monoxide (CO) concentration has been carried out in the EIA report. Predicted increased levels of air pollutant $\mathrm{CO}$ for worst-case scenario was projected based on the existing baseline data. The input parameters required for the CALINE software such as, traffic volume, meteorological parameters (wind speed, wind direction, stability class, mixing height), emission parameters, road geometry, terrain type, background pollutant concentration and receptor location are incorporated after carrying out site-specific study. The maximum concentration of Carbon Monoxide (CO) was found to be in the southwest direction of the proposed development. This ground level concentration of $\mathrm{CO}$ is very meagre and even after summing up with the existing ambient air level shall cause very negligible impact on the existing ambient air of the study area as assessed from the software results. Moreover, it is planned that vehicles plying in the area shall
\end{abstract}


be fitted with the EURO engines complying with the emission standards of India so as to reduce emissions during operational phase of the highway after widening. The detailed impact assessment as well as mitigation measures and the environmental management plan for the proposed project have been prepared.

Keywords: NHAI, vehicular emission, CALINE 4 software, AAQM, traffic density, receptors, line source model, impact assessment, results \& discussion.

\section{Introduction}

National Highway Authority of India (NHAI) under National Highway Development Project (NHDP) Phase III has proposed to develop 4/6 laning of Pune to Solapur section of NH-9 from km. 144.00 to $\mathrm{km} 249.00$ in the state of Maharashtra. The stretch of the 2 lane highway starting at $144.400 \mathrm{~km}$ at Bhima River ends at $249.00 \mathrm{~km}$ at Solapur. The existing length is $104.600 \mathrm{~km}$. There is one congested area where bypass/ realignments have been proposed. Realignment is proposed on left side near Solapur at $\mathrm{km} 241+300$ to $\mathrm{km}$ $249+000$ chainages. The environmental clearance of the said project has been availed from the Ministry of Environment and Forests (MoEF), Govt. of India in the month of September 2011.

The project extends from latitude $18^{\circ} 18^{\prime} \mathrm{N}$ to $17^{\circ} 18^{\prime} \mathrm{N}$ and longitude $73^{\circ} 33^{\prime} \mathrm{E}$ to $76^{\circ} 30^{\prime} \mathrm{E}$. At an altitude of $500.4 \mathrm{~m}$ to $642.4 \mathrm{~m}$ above mean sea level.

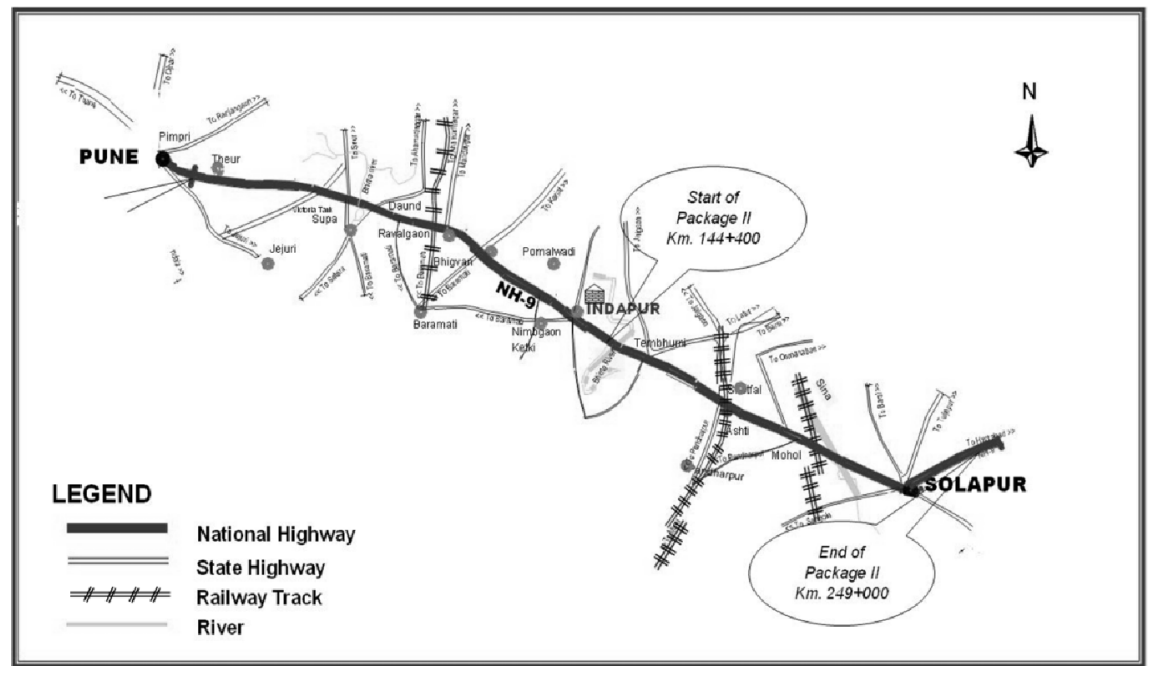

Figure 1: $\quad$ Project location map.

\section{Description of the project}

The proposed project shall require additional $270 \mathrm{Ha}$ of Land for the widening. The raw materials for the same shall be acquired from three aggregate quarries, 
11 borrow areas and single sand quarry. The total water requirement of the proposed project comes to $987 \mathrm{~m}^{3} /$ day. The total cost of the project comes to 835 Crores INR (4175 Million USD.)

\subsection{Existing traffic scenario [1]}

The daily average traffic of the existing highway has been depicted in table 1. It was found that approximately 7678 number of average daily vehicles ply at chainage $170+700,7357$ number of average daily vehicles at ply at chainage $201+000$ and 10600 number of average daily vehicles ply at chainage $234+$ 10600 as per the traffic analysis report for the said project. The traffic load on the highway is projected to reach around 10386 Passenger Car per Unit (PCU) in 2009, 11450 PCU by 2011 and 12022 PCU by 2012.

Table 1: $\quad$ Existing traffic scenario on highway.

\begin{tabular}{|c|c|}
\hline Section & $\begin{array}{c}\text { Average Daily Traffic (ADT) for year 2005 } \\
\text { (Vehicles/Day) }\end{array}$ \\
\hline Ch. $170+700$ & 7678 \\
\hline Ch. $201+000$ & 7357 \\
\hline Ch. $234+200$ & 10600 \\
\hline
\end{tabular}

\section{Baseline environmental status}

The existing baseline environmental status of the area was studies to carry out the impact assessment of the proposed widening. The study was carried out at 9 villages in the area of $10 \mathrm{kms}$ around the project site in order to establish baseline environmental data [2].The various locations selected are given Table 2 and the parameters studied during environmental survey at these locations are indicated in Table 3.

Table 2: $\quad$ Environmental study area.

\begin{tabular}{|c|c|c|}
\hline Sr. No. & Study Location & Distance from Highway \\
\hline 1. & Tembhurni & $0.2 \mathrm{~km}$ \\
\hline 2. & Shetfal & $0.12 \mathrm{~km}$ \\
\hline 3. & Mohol & $0.15 \mathrm{~km}$ \\
\hline 4. & Modnimb & $0.1 \mathrm{~km}$ \\
\hline 5. & Kaegaon & $5.56 \mathrm{~km}$ \\
\hline 6. & Solapur & $0.4 \mathrm{~km}$ \\
\hline
\end{tabular}


Table 3: $\quad$ Parameters studied.

\begin{tabular}{|c|c|c|}
\hline Sr. No & \multicolumn{2}{|c|}{ Parameters } \\
\hline 1. & Air & $\mathrm{PM}_{10}, \mathrm{PM}_{2.5}, \mathrm{SO}_{\mathrm{X}}, \mathrm{NO}_{\mathrm{X}}, \mathrm{CO}$ \\
\hline 2. & Water & $\mathrm{pH}, \mathrm{DO}, \mathrm{PO} 4 \mathrm{NO} 3$ \& heavy metals etc. \\
\hline 3. & Noise & Noise Levels \\
\hline
\end{tabular}

\subsection{Wind}

Onsite Meteorological data for the proposed project was carried out and Wind rose diagram for the same was obtained.

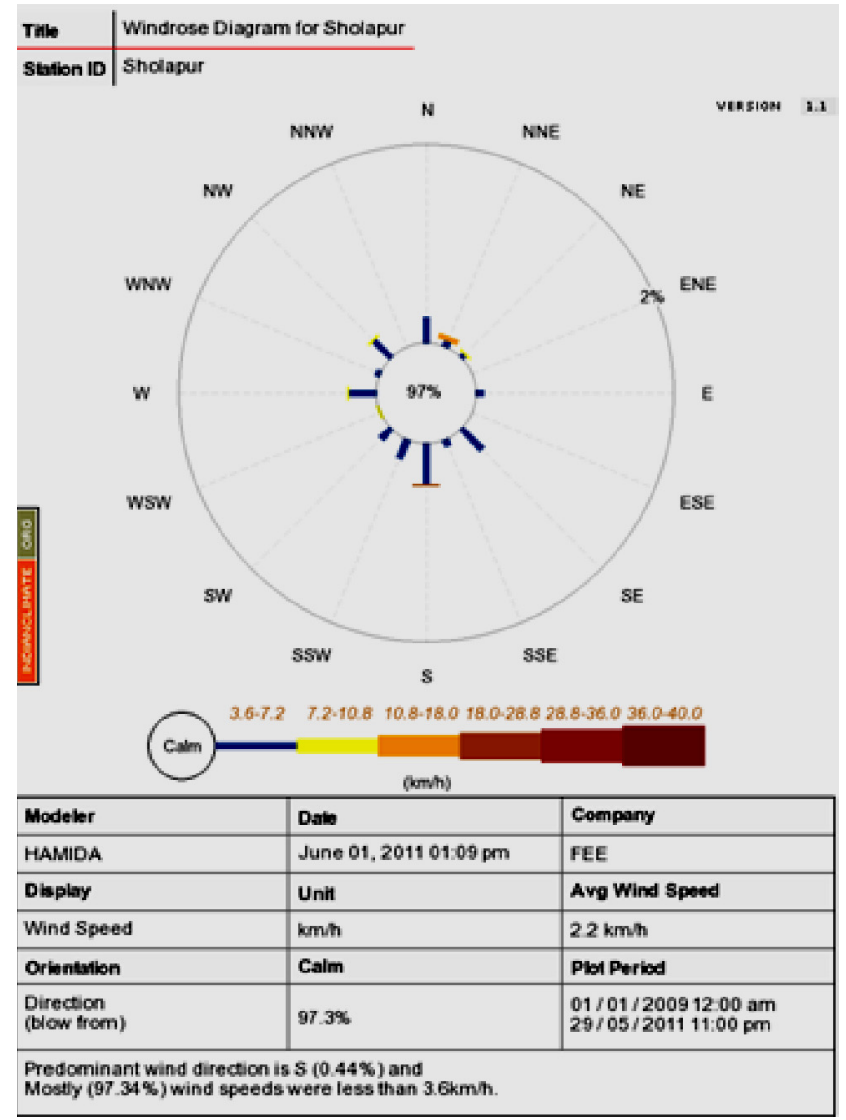

Figure 2: $\quad$ Wind rose diagram of Solapur [3]. 


\subsection{Air quality}

As a part of the environmental impact analysis (EIA) studies air quality was monitored at all the 5 villages coming along the national highway to be widened. The proposed national highway crosses many villages. The impact on air quality due to the proposed development of the highway shall affect these nearby villages the most and thus they are selected for the Baseline data. The baseline ambient air quality data of the region has been monitored during the period of March 2011-May 2011 [2].

\subsubsection{Selection of monitoring stations [2]}

The stations selected for air monitoring are villages that are in the vicinity or intersecting the highway depending upon the prominent wind direction and receptor sensitivity.

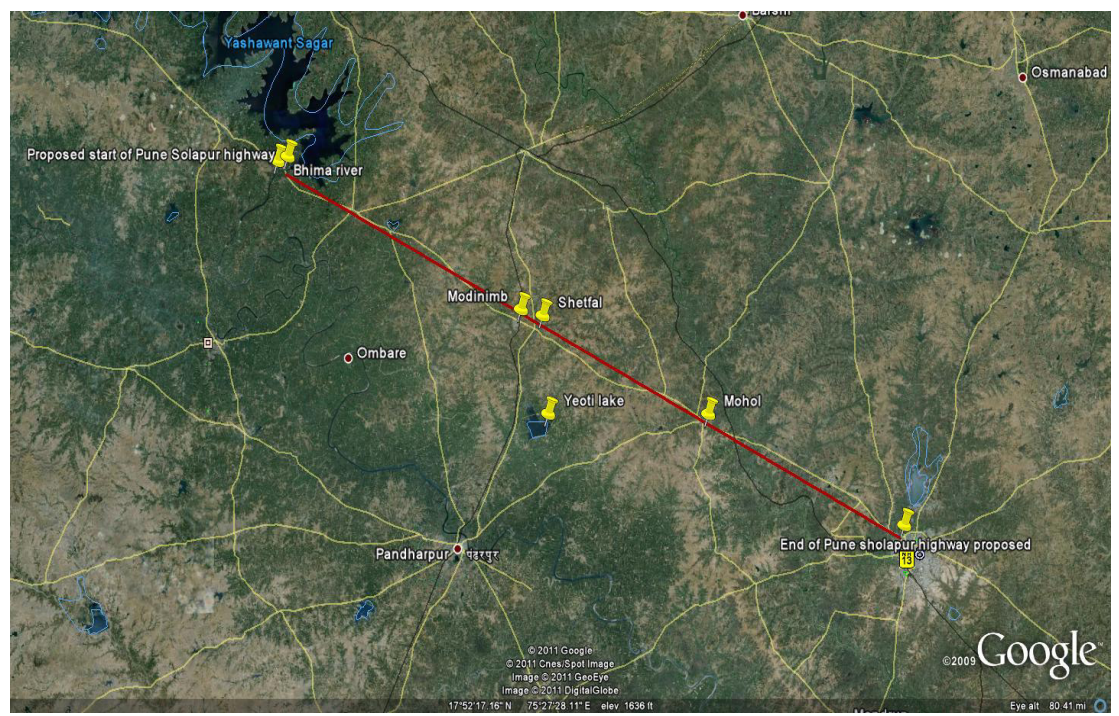

Figure 3: Google image showing sampling location in the study area.

\subsubsection{Monitoring methodology}

Monitoring of ambient air quality was carried out as per Central Pollution Control Board (CPCB) guidelines. The analysis of various air parameters were carried out using Indian Standards. The methods used for analysis as stipulated by $\mathrm{CPCB}$ are presented in table 4 and results in table 5 . As per the observations $\mathrm{PM}_{10}$ is found to be slightly high but within the normal permissible standards at Solapur, Kaegaon and Tembhurni whereas other parameters such as $\mathrm{PM}_{2.5}, \mathrm{SO}_{2}$, and $\mathrm{NO}_{\mathrm{X}}$ were found to be within the permissible limits at all the locations of monitoring within the stretch of the highway. Here $\mu \mathrm{m}$ refers to microns and $\mathrm{mg} / \mathrm{m}^{3}$ refers to microgram per cubic meter. 
Table 4: $\quad$ Ambient Air Quality Monitoring Standards [4].

\begin{tabular}{|c|c|c|c|c|}
\hline \multirow[b]{2}{*}{ Pollutant } & \multirow[b]{2}{*}{$\begin{array}{l}\text { Time } \\
\text { Weighted } \\
\text { Average }\end{array}$} & \multicolumn{2}{|c|}{ Concentration in Ambient Air } & \multirow{2}{*}{$\begin{array}{c}\text { Methods as } \\
\text { per Indian } \\
\text { Standards } \\
\text { (IS) }\end{array}$} \\
\hline & & $\begin{array}{c}\text { Industrial, } \\
\text { Residential, } \\
\text { Rural and } \\
\text { other areas }\end{array}$ & $\begin{array}{c}\text { Ecologically Sensitive } \\
\text { areas notified by } \\
\text { Central Government }\end{array}$ & \\
\hline $\begin{array}{l}\text { Sulphur Dioxide } \\
\left(\mathrm{SO}_{2}\right)\left(\mu \mathrm{g} / \mathrm{m}^{3}\right)\end{array}$ & $\begin{array}{c}\text { Annual } \\
\text { Average* } \\
24 \text { hours** }\end{array}$ & $\begin{array}{l}50 \\
80\end{array}$ & $\begin{array}{l}20 \\
80\end{array}$ & $\begin{array}{l}\text { IS } 5182 \\
\text { Part II. }\end{array}$ \\
\hline $\begin{array}{c}\text { Oxides of } \\
\text { Nitrogen (NOx) } \\
\left(\mu g / m^{3}\right) \\
\end{array}$ & $\begin{array}{c}\text { Annual } \\
\text { Average* } \\
24 \text { hours** }\end{array}$ & $\begin{array}{l}40 \\
80\end{array}$ & $\begin{array}{l}30 \\
80\end{array}$ & $\begin{array}{l}\text { IS } 5182 \\
\text { Part VI. }\end{array}$ \\
\hline $\begin{array}{c}\text { Particulate } \\
\text { Matter (Size less } \\
\text { than } 10 \mu \mathrm{m}) \text { or } \\
\left.\mathrm{PM}_{10} \mu \mathrm{g} / \mathrm{m}^{3}\right)\end{array}$ & $\begin{array}{c}\text { Annual } \\
\text { Average* } \\
24 \text { hours** }\end{array}$ & $\begin{array}{c}60 \\
100\end{array}$ & $\begin{array}{c}60 \\
100\end{array}$ & $\begin{array}{c}\text { IS 5182 } \\
\text { (Part- 23) }\end{array}$ \\
\hline $\begin{array}{c}\text { Particulate } \\
\text { Matter (Size } \\
\text { less than } \\
2.5 \mu \mathrm{m}) \text { or } \\
\mathrm{PM}_{2.5} \mu \mathrm{g} / \mathrm{m}^{3}\end{array}$ & $\begin{array}{c}\text { Annual } \\
\text { Average* } \\
24 \text { hours** }\end{array}$ & $\begin{array}{l}40 \\
60\end{array}$ & $\begin{array}{l}40 \\
60\end{array}$ & $\begin{array}{l}\text { Gravimetri } \\
\text { c Method }\end{array}$ \\
\hline $\begin{array}{c}\text { Carbon } \\
\text { Monoxide } \\
\text { (CO) } \mathrm{mg} / \mathrm{m}^{3}\end{array}$ & $\begin{array}{l}8 \text { hours*** } \\
1 \text { hour** }\end{array}$ & $\begin{array}{l}02 \\
04\end{array}$ & $\begin{array}{l}02 \\
04\end{array}$ & $\begin{array}{l}\text { IS } 5182 \\
\text { Part10. }\end{array}$ \\
\hline
\end{tabular}

*Annual arithmetic mean of minimum 104 measurements in a year at a particular site taken twice a week 24 hourly at uniform levels.

**24 hourly or 08 hourly or 01 hourly monitored values, as applicable, shall be complied with $98 \%$ of the time in a year. $2 \%$ of the time, they may exceed the limits but not on two consecutive days of monitoring.

Table 5: Ambient air quality monitoring data.

\begin{tabular}{|c|c|c|c|c|c|c|}
\hline $\begin{array}{c}\text { Location } \\
\text { ID }\end{array}$ & Locations & \multicolumn{4}{|c|}{ Parameters $(24$ hourly values $)$} & $\begin{array}{c}(8 \text { hour } \\
\text { values })\end{array}$ \\
\cline { 3 - 7 } & & $\begin{array}{c}\mathrm{PM}_{10} \\
\left(\mu \mathrm{g} / \mathrm{m}^{3}\right)\end{array}$ & $\begin{array}{c}\mathrm{PM}_{2.5} \\
\left(\mu \mathrm{g} / \mathrm{m}^{3}\right)\end{array}$ & $\begin{array}{c}\mathrm{SO}_{2} \\
\left(\mu \mathrm{g} / \mathrm{m}^{3}\right)\end{array}$ & $\begin{array}{c}\mathrm{NO}_{\mathrm{X}} \\
\left(\mu \mathrm{g} / \mathrm{m}^{3}\right)\end{array}$ & $\begin{array}{c}\mathrm{CO} \\
\left(\mu \mathrm{g} / \mathrm{m}^{3}\right)\end{array}$ \\
\hline 1 & Tembhurni & $47.2-56.4$ & $14.6-17.32$ & $5.57-6.98$ & $7.56-10.72$ & 0.4 \\
\hline 2 & Shetfal & $39.7-45.5$ & $11.4-13$ & $4.88-5.35$ & $7.21-10.42$ & 0.3 \\
\hline 3 & Mohol & $50.4-51.2$ & $17.8-22.1$ & $6.12-5.98$ & $8.44-11.24$ & 0.5 \\
\hline 4 & Modnimb & $48-53.2$ & $15.5-20.2$ & $6.61-7.91$ & $7.73-11.89$ & 0.41 \\
\hline 5 & Kegaon & $51.2-57.1$ & $19.23-25.4$ & $5.1-6.11$ & $8.45-12.17$ & 0.2 \\
\hline 6 & Solapur & $55.4-59.1$ & $22.1-28.7$ & $6.49-7.45$ & $9.07-13.69$ & 0.7 \\
\hline 7 & $\begin{array}{c}\text { Permissible } \\
\text { Limits }\end{array}$ & 100 & 60 & 80 & 80 & 2 \\
\hline
\end{tabular}




\section{Prediction of impacts}

Prediction of impacts on air environment for the proposed project has been carried out using a line source model CALINE 4. Since the proposed project is of highway widening, the existing highway traffic has been calculated and the proposed traffic has been projected for year 2012 at various junctions of the said highway. The impacts during various phases of the proposed project on the air environment are given below.

\subsection{Preconstruction phase}

Pre-construction phase activities such as site clearance, tree cutting, movement of worker and materials, construction work, construction of haul roads for movement of aggregates and filling materials shall generate negligible amount of dust. Thus particulate matter shall be the predominant pollutant during this phase. Water sprinkling and covering of transportation trucks are the appropriate mitigation measures that will be employed during this stage to reduce the pollution level to acceptable limit.

\subsection{Construction phase}

The important activities during the construction phase that may affect the air quality are identified as heating and mixing of aggregate with bitumen in asphalt mix plant resulting in the emission of gaseous pollutants like $\mathrm{SO}_{2}, \mathrm{NO}_{\mathrm{X}}, \mathrm{CO}$ and $\mathrm{CO}_{2}$, material storage, transportation and handling of construction materials such as sand, fly ash, (if used), earth from borrow pits, aggregates from stone quarries and stone crushing operations resulting in the increase of SPM values, construction and other allied activities, operation of concrete batching plants etc resulting in emission of gaseous pollutants and particulate matter.

\subsection{Operational phase}

During operational stage air pollution generation from vehicular movements on highway are primarily confined to emissions from diesel-powered heavy vehicles and volatile organic carbon emission from vehicular tyres. Besides this there will be gaseous emissions such as $\mathrm{CO}_{2}, \mathrm{HC}$ (Hydrocarbon), $\mathrm{NO}_{\mathrm{X}}$ and $\mathrm{CO}$ from the vehicles plying on the road. PM emissions due to dust flying on the road as well as small amount from the vehicular emission will also impact the air quality of the area. Air quality modelling for $\mathrm{CO}$ and $\mathrm{NO}_{\mathrm{x}}$ was done to access the impacts arising from gaseous emissions on surrounding environment. The PM predication cannot be carried out since the software does not support the prediction of particulate matter as a whole, moreover emission co-efficient for the particulate matter of different sizes has not been devised. The said prediction was done using CAlifornia LINE Source Dispersion Model (CALINE4) [5]. 


\section{CAlifornia LINE source dispersion model (CALINE4) modelling}

CL4 is a graphical windows-based user interface, designed to ease data entry and increase the on-line help capabilities of CALINE-4 [5]. The CL4 setup program is self-contained, so the user only needs to complete a single installation step. The original CALINE4 executable files are copied to the CL4 program directory.

\subsection{Input requirement}

The highway dispersion model requires the following data as input - traffic parameters such as traffic volume (hourly and peak), meteorological parameters: (wind speed, wind direction, stability class, mixing height), emission parameters (expressed in grams/distance travelled), road geometry (road width, median width, and length), type of terrain (urban or rural, flat or hilly), background concentration of pollutants and receptor location.

\subsection{Emission factor}

The emission factor used in this study is given in table below.

Table 6: $\quad$ Emission factors for criteria pollutant [6].

\begin{tabular}{|l|c|c|}
\hline S. No & Pollutant & Emission factor $(\mathrm{g} / \mathrm{km} / \mathrm{PCU})$ \\
\hline 1. & $\mathrm{CO}$ & 13.00 \\
\hline 2. & NOx & 2.00 \\
\hline
\end{tabular}

\subsection{Traffic density}

A detailed study of the traffic density along the project road as well as the predicted traffic scenario till year 2012. Maximum hourly PCU for the years is projected in Table 7.

Table 7: $\quad$ Projected Traffic (PCU).

\begin{tabular}{|c|c|c|c|}
\hline Year & 2009 & 2011 & 2012 \\
\hline Package-II & 10386 & 11450 & 12022 \\
\hline
\end{tabular}

The project Traffic for year 2012 has been considered for impact prediction.

\subsection{Meteorological data}

For this study, worst-case meteorological input of low wind speed $(2 \mathrm{~m} / \mathrm{s})$, ambient temperature $35^{\circ} \mathrm{C}$ and stability class $\mathrm{F}$ was considered. 


\subsection{Receptors}

A total of 3 receptors near the said highway were selected for prediction of ground level concentrations due to the existing and proposed traffic on the project road.

\subsection{Results and discussion}

The increase in traffic due to the proposed project shall directly impact vehicular emission pollutants such as $\mathrm{CO}, \mathrm{NO}_{\mathrm{x}}$ (Oxides of Nitrogen), $\mathrm{PM}_{10}, \mathrm{HC}$ and $\mathrm{SO}_{2}$. The predicted maximum ground level concentration (GLC) for $\mathrm{CO}$ and $\mathrm{NO}_{2}$ (Oxides of Nitrogen in terms of Nitrogen Dioxide) was derived with help of CALINE-4 software. The prediction for $\mathrm{CO}$ was conducted for 8-hourly concentration (conc.) and for $\mathrm{NO}_{2}$ was conducted for 24-hourly concentration. The output result of the software is given below. A graphical representation of the same has been depicted in figure.4. As per the graph in figure 4, it has been observed that there will be slight increase in $\mathrm{CO}$ levels after the said project, due to the increase in vehicular traffic of the highway. $\mathrm{NO}_{2}$ does not have significant environmental baseline concentration in terms of $\mu \mathrm{g} / \mathrm{m}^{3}$ (microgram per cubic meter) which comes to a very negligible value when converted to ppm (parts per million). The input unit for Caline Software being in ppm, the $0.007 \mathrm{ppm}$ value of $\mathrm{NO}_{2}$ gets nullified and simulation indicates extremely low values that cannot be effectively predicted. Hence, the predicted $\mathrm{NO}_{2}$ concentration shows no prominent increase after the proposed project thus the impact is negligible.

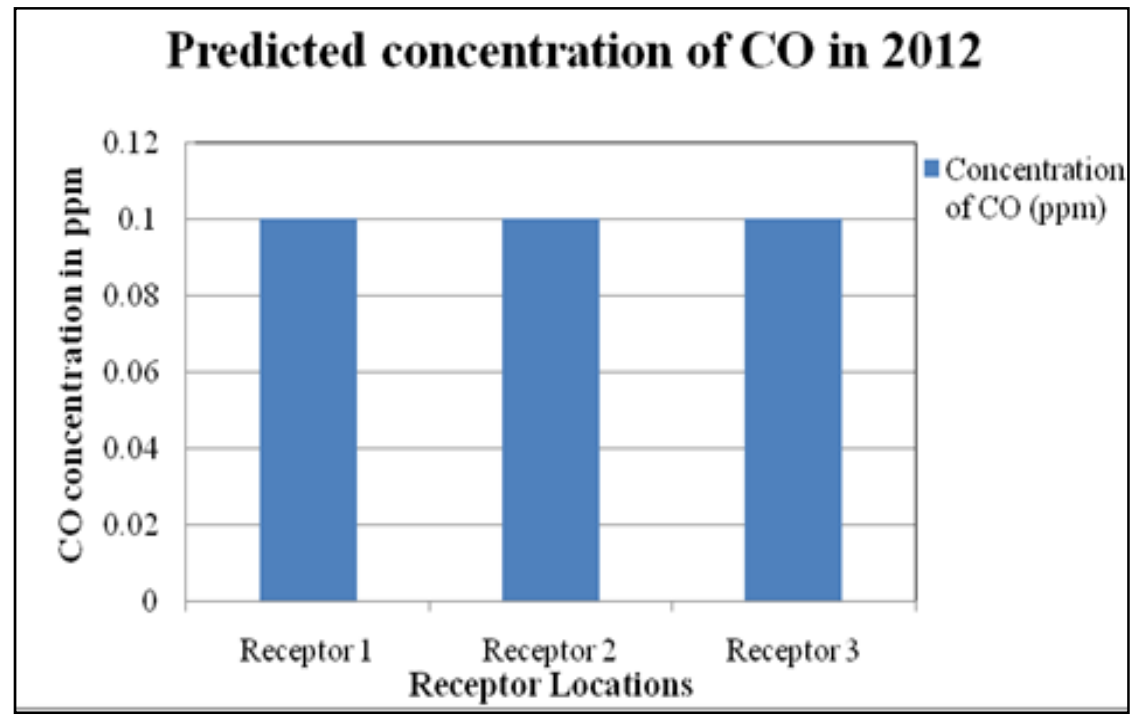

Figure 4: Prediction of CO concentration in worst case scenario for the year 2012. 
Particulate Matter being the major pollutant amongst them, it is important to address predicted $\mathrm{PM}_{10}$ concentration from the said project, however the Emission factor for $\mathrm{PM}_{10}$ is not available (Total Suspended particle emission factor is available), moreover the conversion of $\mathrm{PM}_{10}$ from $\mu \mathrm{g} / \mathrm{m}^{3}$ to $\mathrm{ppm}$ is not possible since we cannot obtain Molecular weight of particulate matter as a whole. Thus prediction of concentration for Particulate Matter cannot be addressed through Caline Software. It is envisaged that the other pollutants such as $\mathrm{HC}, \mathrm{SO}_{2}$ will also show some increase in concentration after the said project, however it will be very negligible and adhere to the standard limits. Adequate preventive measures have to be planned to counter this aspect. The provision of greenbelt around the roads as well as on the road median shall result in a localized cushioning of air pollution. This would also help in curbing the ill effects of $\mathrm{CO}$ emission.

Table 8: $\quad$ Model output results.

\begin{tabular}{|c|c|c|c|c|c|c|c|c|}
\hline $\begin{array}{c}\text { Sr. } \\
\text { No }\end{array}$ & Receptor & Degrees & \multicolumn{2}{|c|}{$\begin{array}{c}\text { Predicted conc. } \\
\text { of CO }\end{array}$} & $\begin{array}{c}\text { Predicted conc. } \\
\text { of NOx }\end{array}$ & \multicolumn{2}{|l|}{ Conc./Link (ppm) } \\
\cline { 3 - 9 } & & $(\mathrm{ppm})$ & $\left(\mathrm{mg} / \mathrm{m}^{3}\right)$ & $(\mathrm{ppm})$ & $\mathrm{A}$ & $\mathrm{B}$ & $\mathrm{C}$ \\
\hline 1. & $\begin{array}{c}\text { Receptor } \\
1\end{array}$ & 114 & 0.1 & 0.114 & 0 & 0.0 & 0.0 & 0.0 \\
\hline 2. & $\begin{array}{c}\text { Receptor } \\
2\end{array}$ & 114 & 0.1 & 0.114 & 0 & 0.0 & 0.0 & 0.0 \\
\hline 3. & $\begin{array}{c}\text { Receptor } \\
3\end{array}$ & 145 & 0.1 & 0.114 & 0 & 0.0 & 0.0 & 0.0 \\
\hline
\end{tabular}

\section{Observation}

The baseline concentration for Carbon Monoxide (CO), Oxides of Nitrogen as Nitrogen dioxide $\left(\mathrm{NO}_{2}\right)$ have been monitored, the predicted concentration of $\mathrm{CO}$ and $\mathrm{NO}_{2}$ for the worst case scenario due to the proposed widening project have been derived to be $0.1 \mathrm{ppm}\left(0.114 \mu \mathrm{g} / \mathrm{m}^{3}\right)$ for $\mathrm{CO}$ and $0 \mathrm{ppm}$ for $\mathrm{NO}_{2}$. The negligible value of $\mathrm{NO}_{2}$ simulation can be credited to the non-significant value of baseline $\mathrm{NO}_{2}$ concentration which further decreases when converted into ppm making it difficult to be predicted through the Caline software. As discussed earlier the $\mathrm{PM}_{10}$ simulation cannot be carried out since its emission co-efficient does not exist. The total maximum concentration in ambient air for $\mathrm{CO}$ for the proposed 4/6 laning of existing 2-Lane highway stretch from Bhima river to Solapur of NH-9 that has been predicted is given in table 9. The results show that the predicted concentration of the proposed area shall conform to the standard 
limits as per National Ambient Air Quality Standards (NAAQS) by Ministry of Environment and Forests (MoEF), Govt. of India.

Table 9: Maximum ambient air concentration of Carbon Monoxide (CO) predicted to increase after the proposed project.

\begin{tabular}{|c|c|c|c|c|c|}
\hline Location & $\begin{array}{c}\text { Baseline } \\
\text { Concentration } \\
\text { in Ambient Air }\end{array}$ & $\begin{array}{c}\text { Maximum predicted } \\
\text { GLC (ground level } \\
\text { concentration) }\end{array}$ & $\begin{array}{c}\text { Maximum Concentration in } \\
\text { Ambient Air After starting } \\
\text { of the proposed project }\end{array}$ & $\begin{array}{c}\text { Permissible } \\
\text { Limits [1] }\end{array}$ \\
\cline { 2 - 6 } & $(\mu \mathrm{g} / \mathrm{m} 3)$ & $\begin{array}{c}8 \mathrm{hr} \text { Worst Case } \\
\text { Concentration }\end{array}$ & $\left(\mathrm{mg} / \mathrm{m}^{3}\right)$ & $\left(\mu \mathrm{g} / \mathrm{m}^{3}\right)$ \\
\cline { 2 - 6 } & {$[\mathrm{A}]$} & $\left(\mathrm{mg} / \mathrm{m}^{3}\right)$ & Direction & {$[\mathrm{A}+\mathrm{B}]$} & \\
\hline Tembhurni & 0.4 & 0.114 & 114 & 0.5 & 2 \\
\hline Shetfal & 0.3 & 0.114 & 114 & 0.4 & 2 \\
\hline Mohol & 0.5 & 0.114 & 114 & 0.6 & 2 \\
\hline Modnimb & 0.41 & 0.114 & 114 & 0.51 & 2 \\
\hline Kegaon & 0.2 & 0.114 & 114 & 0.3 & 2 \\
\hline Solapur & 0.7 & 0.114 & 114 & 0.8 & 2 \\
\hline
\end{tabular}

\section{Conclusion}

It may be noted that the concentration of Carbon Monoxide $(\mathrm{CO})$ as predicted through CALINE software in worst case scenario is the maximum predicted value for the proposed development. The actual values shall not exceed this limit. However the predicted maximum ambient air concentration of $\mathrm{CO}$ value after the proposed project shall conform the standard permissible limits of National Ambient Air Quality Standards (NAAQS), dated $18^{\text {th }}$ November, 2009 [1]. Therefore, it can be concluded that the said section of NH-9 shall have no major impact on air pollution as predicted from above modeling studies. The said case was presented at the Ministry of Environment and Forests (MoEF), Govt. of India on $22^{\text {nd }}$ September, 2011 and received Environmental Clearance from the Expert Appraisal Committee.

\section{References}

[1] Pre-feasibility report for "widening of Pune-Solapur National Highway under NHDP Phase-III.

[2] As per EIA Notification under Environmental Protection Rules, 1986 published under ministry of Environment and Forests (MoEF), dated $14^{\text {th }}$ September, 2006 and amended on $16^{\text {th }}$ November, 2009.

[3] Software WRPlot View from Lakes Environment at http://www.weblakes.com/.

[4] Schedule VII, Rule 3(3b) "National Ambient Air Quality Standards" in Ministry of Environment and Forest's (MoEF) Notification under Gazette of India at New Dehli on 16th November, 2009. 
58 Air Pollution XX

[5] CAlifornia LINE Source Dispersion Model (CALINE4) by the California Department of Transportation (Caltrans).

[6] Gurjar et al (2004). "Emission estimates and trends (1990-2000) for megacity Dehli and implications". Atmospheric Environment, 38, pp. 56635681. 